\title{
Identifikasi Genotype Rumah Adat Sumba Barat dengan Metode Space Syntax
}

\author{
Irfan Irwanuddin 1 \\ ${ }^{1}$ Magister Arsitektur/Sekolah Arsitektur, Perencanaan, dan Pengembangan Kebijakan, Institut Teknologi \\ Bandung \\ irfanirwanuddin@gmail.com
}

\begin{abstract}
ABSTRAK
Berbagai pengaruh terhadap morfologi rumah tradisional Sumba Barat menyebabkan eksterior rumah di beberapa desa adat memiliki kesamaan bentuk. Meskipun secara eksterior terlihat sama, masing-masing rumah tersebut memiliki konfigurasi ruang yang berbeda-beda. Konfigurasi ruang merupakan produk dari faktor sosial budaya suatu masyarakat. Dengan kata lain, kondisi sosial yang berbeda dari suatu masyarakat akan menghasilkan arsitektur dengan konfigurasi ruang yang berbeda pula. Sementara itu, metode space syntax dinilai mampu mengurai fenomena sosial melalui aspek konfigurasi ruang tersebut dengan metode yang terukur. Maka dari itu, penelitian ini berupaya menggali genotype dari perbedaan konfigurasi ruang interior beberapa rumah di desa adat Sumba Barat. Tujuan dari penelitian ini adalah untuk mengungkap fenomena sosial yang terjadi berdasarkan pola yang nampak melalui konfigurasi ruang. Core dan territory, merupakan sebagian aspek dari arsitektur yang dapat menjadi representasi budaya dari suatu masyarakat tertentu. Hasil penelitian mengungkap bahwa terdapat pola spasial yang sama pada masingmasing studi kasus. Pola spasial ini terungkap melalui perbandingan core dan territory masing-masing studi kasus. Empat dari kelima studi kasus menunjukkan adanya ikatan kesamaan genotype yang kuat, sementara satu studi kasus menunjukkan genotype yang berbeda. Sementara itu, terdapat fakta bahwa rumah dengan genotype yang berbeda tersebut berada pada satu desa yang telah terpapar pengaruh modernisasi.
\end{abstract}

Kata kunci: space syntax, arcitektur vernakular, rumah sumba barat, genotype.

\begin{abstract}
Various influences toward West Sumba traditional house's morphology are affecting the way its exterior appearance has formed. Despite their exterior uniformity, each of these houses is showing different spatial configuration. Spatial configuration is a product of certain social processes. In other words, different society will produce different spatial configuration. Meanwhile, it is believed that space syntax method could be employed to elaborate objectively particular social phenomenon by examining its spatial configuration. Based on that, this research attempted to identify the genotype in those houses to reveal the social phenomenon occurred. Core and territory are parts of several factors that potentially represent a cultural pattern in certain society. The result revealed that these houses are in fact sharing same spatial patterns. It is strongly indicated by core and territory pattern comparison. Four of the five samples are showing a strong genotype, while the left one is showing a genotype differences. In addition, there is a fact that this house with different genotype is located in a village that exposed to modernization.
\end{abstract}

Keywords: space syntax, vernacular architecture, west sumba, genotype. 


\section{Pendahuluan}

Dari berbagai penelitian, ditemukan adanya pengaruh budaya terhadap arsitektur suatu masyarakat tertentu. Dawson (2002) dalam penelitiannya mengungkap bahwa aktivitas manusia dan proses sosial memiliki kebutuhan yang unik antar satu dengan lainnya yang terwujud dalam ruang. Pola sosial dari suatu masyarakat tertentu akan menghasilkan tatanan ruang yang spesifik berdasarkan nilai-nilainya yang dianut. Jika dalam suatu masyarakat terdapat pergeseran dari nilai yang dianut, maka tatanan ruang dari arsitekturnya akan berubah pula.

Fenomena pariwisata merupakan faktor paling berpengaruh dalam transformasi suatu pemukiman vernakular (Nepal, 2010). Bahkan, dalam studinya, Dincyurek (2005) menilai bahwa turisme berpotensi sebagai ancaman bagi keberlanjutan pemukiman vernakular. Sumba Barat sebagai salah satu destinasi wisata yang saat ini cukup diunggulkan di Indonesia, tidak menutup kemungkinan pula dapat terkena dampak transformasi tersebut. Selain keindahan alamnya, salah satu daya tarik dari pariwisata tersebut adalah keunikan rumah adat yang tersebar di beberapa desa. Selain dari bentuk rumah adatnya, terdapat pula kaitan erat antara spasial dan sosial dari masyarakatnya yang secara bersamaan membentuk keunikan tersebut dan menjadikannya menarik bagi para wisatawan. Maka dari itu, dengan melakukan pengamatan pada konfigurasi spasial rumah tradisional Sumba Barat, maka pengetahuan mengenai arsitektur rumah adat Sumba Barat dapat lebih terjaga.

Di Sumba Barat, terdapat beberapa desa dengan sekumpulan rumah tradisionalnya yang hingga kini masih bertahan. Dalam bahasa Sumba, kata 'desa' disebut sebagai 'parona' atau 'paraingu'. Sebagian dari desa tersebut diantaranya adalah Parona Tossi, Parona Waikahumbu, Parona Ratenggaro, Parona Tarung, dan Paraingu Kabonduk (Winandari, 2006). Meskipun di antara desa tersebut tipologi eksterior rumah tradisionalnya menunjukkan kesamaan bentuk fisik, namun dalam pola penataan ruang denah interiornya tempak berbeda.

Masyarakat Sumba Barat, dengan sistem kepercayaan yang disebut Marapu, memiliki pengaruh dalam penataan rumah tinggalnya. Sistem kepercayaan ini menganut prinsip bahwa leluhur yang telah tiada masih hidup berdampingan di desa dan menjadi bagian dari kehidupan sehari - hari mereka. Hal ini tampak melalui adanya ruang di dalam rumah yang secara konsisten disediakan masyarakat Sumba Barat untuk leluhur mereka. Melalui suatu upacara tertentu, masyarakat dapat berhubungan dengan leluhur mereka di ruang pusat yang disebut rabok/dapur yang di kelilingi oleh 4 kolom utama (Hariyanto, 2012). Namun, dari sudut pandang hubungan ruang, ciri khusus ruang pusat ini belum dapat dibuktikan secara obyektif.

Penelitian ini bertujuan untuk mengungkap genotype dari rumah tradisional Sumba Barat. Genotype merupakan konsep munculnya konsistensi dalam konfigurasi ruang dari beberapa bangunan berbeda yang menunjukkan adanya kesamaan pola budaya yang sama (B Hillier, Hanson, \& Graham, 1987). Kesamaan sistem kepercayaan yang dianut oleh masyarakat Sumba Barat tersebut menjadi fenomena dalam mengungkap lebih dalam bagaimana pola dari kesamaan tersebut termanifestasi dalam konfigurasi spasial. Melalui metode space syntax, penelitian ini berupaya mengungkap apakah pola yang dihasilkan akan membentuk konsistensi tertentu. Selain itu, tujuan dari metode ini adalah sebagai dasar dalam menggali pemahaman mengenai fenomena sosial yang terjadi di dalam arsitektur masyarakat Sumba Barat.

\section{Metode Space Syntax}

Secara khusus, Melalui artefak phenotype (denah ruangan), metode analisis space syntax dapat digunakan untuk mengungkap genotype dari konfigurasi ruang. Genotype 
adalah suatu hubungan abstrak (in-tangible) yang menentukan terciptanya fisik phenotype (tangible). Maka dari itu, dengan mengamati aspek spasial dari Rumah Sumba Barat, genotype yang menjadi dasar penyusunan konfigurasi ruang rumah tersebut dapat diungkap. Dasar dari penggunaan metode space syntax ini adalah adanya nilai sintaksis yang dapat dihasilkan dari analisis yang menurut penelitian Thungsakul (2001) berperan membantu menggali maupun menjelaskan hubungan antara ruang dan konteks sosial budaya pada suatu lingkungan binaan.

Konsep 'social logic' dari space syntax pertama-tama dilakukan dengan menganalogikan ruang ruang interior sebagai cell. Jika satu rumah terdiri dari lima ruangan maka dapat dikatakan bahwa rumah tersebut terdiri dari lima cell, sementara hubungan antar cell di dalam rumah tersebut di sebut sebagai permeability. Maka dari itu, dalam menganalisis konfigurasi ruang, analisis space syntax terlebih dahulu dilakukan dengan membangun apa yang disebut dengan justified permeability graph (JPG). Di dalam JPG, ruang dan hubungannya digambarkan melalui konsep node dan link, dimana node mewakili cell tersebut, sedangkan link menggambarkan permeability (Gambar 1). Sebelum membangun JPG, salah satu ruang di dalam denah harus ditentukan dahulu sebagai 'root' dari keseluruhan struktur. Dengan begitu, relativitas kedalaman satu ruang terhadap ruang lainnya dapat dianalisis. Sebagai contoh, di dalam Gambar 2, terdapat dua denah yang memiliki konfigurasi ruang yang berbeda, meskipun keduanya memiliki tampilan dan relativitas root yang sama, yakni pada ruang C. Seluruh ruang yang berada pada tingkat kedalaman yang sama akan diposisikan pada garis horizontal yang sama, tanpa mempertimbangkan seberapa jauh jarak yang ditempuh dalam mencapai ruang tersebut dalam satuan jarak. Sedangkan ruang yang berada pada tingkat kedalaman berbeda akan diposisikan dalam garis horizontal yang berbeda. Dengan membangun JPG, struktur topologis dari konfigurasi ruang dapat dijelaskan melalui logika hubungan ruang yang lebih mudah dibaca.

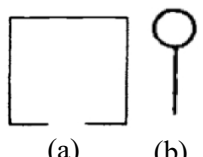

Gambar 1. Konsep link dan node (b) yang diterjemahkan berdasarkan denah ruang (a). (Sumber: Hillier, B, 1984)

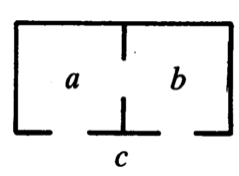

(a)

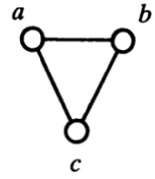

(b)

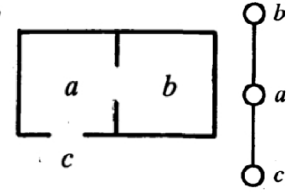

(c)

(d)

Gambar 2. Konfigurasi ruang pada denah a menghasilkan JPG b. Konfigurasi ruang pada denah c menghasilkan JPG d.

(Sumber: Hillier, B et al., 1987)

Komponen analisis dari konfigurasi yang direpresentasikan oleh JPG salah satunya adalah properti depth. Sebuah ruangan dinyatakan memiliki kedalaman satu depth apabila jika dalam mencapai ruang tersebut, transisi yang diperlukan hanya melewati satu node untuk mencapai tujuan. Dengan kata lain, jika dalam mencapai satu ruang diperlukan untuk melewati empat ruang lainnya, maka ruangan tersebut dianggap memiliki empat depth. Semakin banyak ruang yang harus dilewati dalam mencapai suatu ruangan, maka dapat dikatakan bahwa ruangan tersebut disebut memiliki privasi yang 
semakin tinggi. Properti ini sangat penting dalam mengurai unsur budaya dan sosial yang berkaitan dengan sakral-profan.

Selain itu, komponen analisis yang dapat digunakan dalam mengurai unsur konfigurasi ruang lainnya adalah komponen integrasi. Melalui JPG, jika suatu node yang mewakili satu ruang memiliki keterhubungan yang paling tinggi dibanding ruang lain, maka dapat dikatakan bahwa ruang tersebut memiliki tingkat integrasi yang paling tinggi dibanding ruang lainnya. Dengan catatan, terdapat pengaruh relativitas dari jumlah ruangan keseluruhan. Hal ini juga berlaku sebaliknya, yakni jika suatu ruang memiliki keterhubungan yang semakin rendah, maka ruang tersebut memiliki tingkat integrasi yang semakin rendah pula. Untuk analisis yang lebih dalam, formulasi dari nilai integrasi suatu ruang itu sendiri dapat dilakukan menggunakan rumus:

$$
\text { integration value }=\frac{2(\bar{d}-1)}{k-2}
$$

Rumus 1. Nilai integrasi

(Sumber: B Hillier et al., 1987)

Dimana d menunjukkan rata-rata depth dari keseluruhan ruangan terhadap satu ruangan dan k menunjukkan jumlah keseluruhan ruangan. Nilai integrasi ini kemudian dapat mengekspresikan secara numerik aspek konfigurasi ruang yang sebelumnya dibentuk secara visual dalam JPG, sehingga peringkat hirarkis sakral-profan suatu konfigurasi ruang dapat terlihat.

Perbedaan konfigurasi ruang umumnya menghasilkan nilai integrasi yang berbeda. Dengan JPG, hal ini dapat direpresentasikan secara visual. Sedangkan dengan kalkulasi nilai integrasi, hal ini dapat direpresentasikan melalui angka. Jika nilai-nilai pada masing-masing studi kasus menunjukkan adanya konsistensi, maka dapat dikatakan bahwa di antara studi kasus tersebut terdapat genotype yang kuat. Sebaliknya, jika terdapat inkonsistensi pada beberapa studi kasus, maka dapat dikatakan bahwa terdapat ikatan genotype yang tidak kuat. Seluruh kalkulasi tersebut, dalam penelitian ini dilakukan dengan menggunakan perangkat lunak DepthmapX versi 0.50 yang dikembangkan oleh University of College London.

\subsection{Penelitian Terdahulu}

Beberapa penelitian telah berhasil mengungkap genotype sekumpulan bangunan berdasarkan denah ruangannya masing-masing menggunakan metode space syntax. Salah satunya adalah penelitian dengan studi kasus rumah di area permukiman rural di prancis yang telah dilakukan oleh B Hillier et al., (1987). Secara umum, penelitian ini berhasil mengungkap 8 rumah yang menunjukkan kesamaan genotype dari 14 kasus rumah yang dikaji melalui adanya konsistensi nilai integrasi yang polanya terlihat pada satu ruangan yang konsisten. Kemudian, terdapat penelitian dengan studi kasus rumah Persia yang telah dilakukan Nazidizaji \& Safari (2014). Penelitian ini mengungkap adanya kesamaan tingkat integrasi yang tinggi di ruang halaman tengah. Selain itu melalui analisis depth, terungkap pula bahwa studi kasus menunjukkan tingkat kedalaman yang sama. Kemudian, penelitian dengan studi kasus rumah di Nigeria yang dilakukan oleh Adeokun (2013). Hasil dari penelitian ini menunjukkan adanya genotype melalui beberapa pola, yakni adanya konsistensi nilai integrasi pada ruang yang disebut orowa, pengaruh konfigurasi yg besar dari ruang-ruang dead-end, dan adanya kesamaan tingkat kedalaman yang rendah.

Ketiga contoh penelitian di atas menunjukkan bahwa konsep genotype dari sekumpulan rumah dapat diindikasikan melalui aspek yang berbeda-beda. Hal ini disebabkan adanya perbedaan fenomena sosial penghuni dari masing-masing studi kasus 
yang ada. Sementara dalam penelitian ini, pola-pola konfigurasi ruang yang diamati dalam menggali genotype pada studi kasus menggunakan dasar pemikiran elemen budaya yang disebut Rapoport (1977) sebagai core dan territory. Kedua aspek ini merupakan dua dari lima unsur arsitektur yang menurut Rapoport dapat merepresentasikan kondisi budaya suatu masyarakat. Kedua aspek tersebut sejalan dengan prinsip analisis space syntax yang berprinsip bahwa aspek core suatu tatanan ruang dapat digali melalui analisis integrasi, sementara aspek territory ini dapat digali melalui analisis depth.

\section{Rumah Sumba Barat}

Rumah adat ini berlokasi tersebar di beberapa desa di Sumba Barat. Meskipun terbagi menjadi beberapa desa, rumah adat ini memiliki ciri khas yang sama, yakni atap limas menyerupai joglo yang menjulang tinggi, bentuk panggung sebagai area hewan ternak, serta proporsinya yang simetris. Terlihat pada Gambar 3 dan Gambar 4, bahwa eksterior rumah adat di beberapa desa ini memiliki kesamaan bentuk, meskipun secara interior, terdapat perbedaan konfigurasi ruang seperti yang terlihat pada Gambar 5 dan Gambar 6.

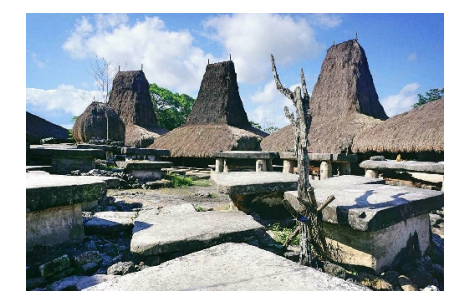

Gambar 3. Eksterior rumah

Parona Ratenggaro

(Sumber: http://itchcreature.com)

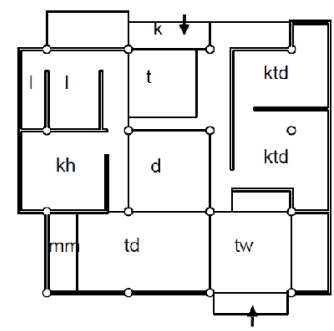

Gambar 5. Interior rumah

Parona Ratenggaro

(Sumber: Winandari, 2006)

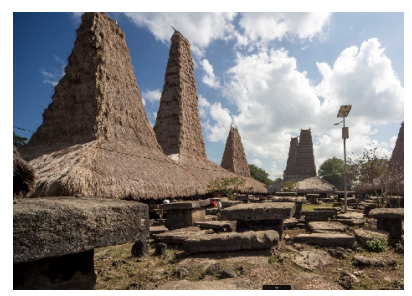

Gambar 4. Eksterior rumah

Parona Tarung

(Sumber: http://tukangjalan.com)

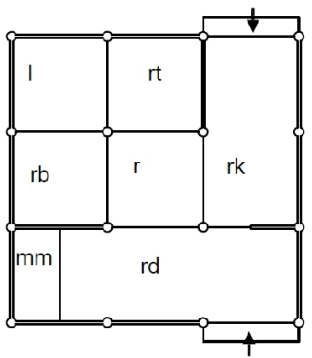

Gambar 6. Interior rumah

Parona Tarung

(Sumber: Winandari, 2006)

Kebanyakan masyarakat Sumba masih memegang sistem kepercayaan Marapu. Marapu merupakan konsep kepercayaan yang mempercayai bahwa arwah leluhur yang telah meninggal tetap hidup di antara masyarakat Sumba dan dapat dimintai perlindungan dan berkah (Topan, 2005). Selain itu, konsep Marapu ini juga mempercayai adanya wujud Ilahi yang dinamakan "Mawolu Marawi" yang berarti pencipta segala sesuatu. Yang berkuasa atas hidup dan mati manusia serta seluruh alam dan iman atau leluhur (Tim Peneliti Widya Mandira, 1992). Sistem kepercayaan ini memiliki pengaruh yang holistik pada aspek kehidupan masyarakat tradisional Sumba, termasuk di dalamnya adalah arsitektur. Pengaruh kosmologi dalam tatanan ruang rumah tradisional Sumba Barat ini diantaranya adalah menciptakan pemisahan ruang sakral-profan yang terjadi secara vertikal maupun horizontal. 
Masyarakat Sumba dalam budaya bermukimnya mengenal tiga jenis rumah, yaitu rumah adat, rumah dusun, dan rumah kebun. Dari ketiga jenis rumah tersebut, penelitian ini berfokus pada jenis rumah adat. Hal ini didasari adanya kegiatan ritual kepercayaan yang berlangsung di rumah adat. Sehingga pengaruh kosmologi terhadap konfigurasi ruang pada rumah Adat lebih kuat jika dibandingkan dengan rumah dusun dan rumah kebun.

\subsection{Eksterior}

Pulau Sumba merupakan salah satu pulau dari gugusan pulau di provinsi Nusa Tenggara Timur. Pulau ini memiliki karakteristik topografi yang secara umum berbukitbukit dan cenderung kering, serta kawasan yang didominasi oleh area hutan yang heterogen. Kesamaan geografis makro serta iklim yang tropis antara lain merupakan penyebab kesamaan bentuk atap limasan yang tinggi dari Rumah Sumba Barat yang khas. Atap limasan yang tinggi tersebut di topang oleh 4 kolom utama, yang jika dilihat melalui denahnya, memiliki posisi sebagai core bangunan (Gambar 5 \& 6).

Tradisi berkuda dari masyarakat Sumba merupakan faktor lainnya yang mempengaruhi tipologi rumah Sumba yang berbentuk panggung. Ketinggian panggung umumnya disesuaikan dengan ketinggian punggung kuda (Gambar 7) atau setinggi pundak orang dewasa. Bentuk panggung dari rumah ini juga merupakan salah satu ciri umum yang menjadi kesamaan eksterior diantara berbagai desa tradisional di Sumba Barat.

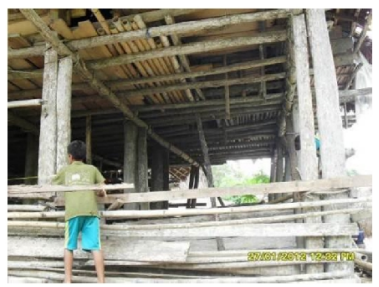

Gambar 7. Bagian bawah panggung rumah Sumba.

(Sumber: Hariyanto, dkk, 2012)

Secara umum eksterior rumah Sumba Barat ini berbentuk simetris, dengan layout persegi. Kesamaan dari bentuk atap dan bentuk panggung dari rumah adat Sumba Barat ini terdapat pada seluruh desa adat di Sumba.

\subsection{Interior}

Dalam penelitian Kusumawati dkk (2007), secara vertikal hirarki sakral-profan dalam rumah tradisional Sumba Barat terbagi menjadi tiga, yakni uma deta (atas), uma bei (tengah), dan kali kambunga (bawah) (Gambar 8). Uma deta memiliki makna yang berarti tempat bersemayamnya roh nenek moyang. Area ini merupakan area paling sakral dan tidak ada aktivitas sosial terjadi di dalamnya. Uma bei berperan sebagai tempat kehidupan sosial manusia. Area ini paling sering digunakan dalam keseharian masyarakat Sumba Barat dan secara jarak pandang masih bersinggungan dengan uma deta. Kemudian kali kambunga sebagai tempat hewan, yakni ruang paling profan. Area ini merupakan area paling bawah yang tidak dapat di akses melalui di uma bei. Berdasarkan fakta tersebut, maka dalam menggali suatu genotype, jenis ruang yang perlu diamati adalah ruang-ruang yang berada dalam hirarki uma bei. Sebab, ruang tersebut merupakan tempat dimana terjadinya aktivitas sosial penghuni sehingga kemungkinan hadirnya pola spasial terkait aktivitas akan lebih terlihat. 


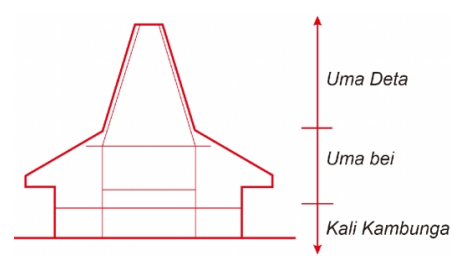

Gambar 8. Pembagian ruang vertikal pada rumah.

(Sumber: Hariyanto, dkk, 2012).

Menurut penelitian Hariyanto, dkk (2012) secara horizontal masyarakat Sumba Barat membagi ruang-ruangnya berdasarkan fungsi dan gender. Pembagian ruang ini lebih banyak terjadi pada area uma bei. Secara gender, masyarakat Sumba Barat membagi area pintu masuk menjadi dua baik secara depan/belakang maupun kanan/kiri, sedangkan secara fungsi, pembagian ruang tersebut lebih banyak terjadi secara radial, yakni memusat pada area tengah. Ruang memasak oleh masyarakat Sumba Barat dipercaya memegang peranan penting sebagai area "jantung" Marapu.

\section{Problem dan Kasus}

Winandari, dkk (2006) dalam penelitiannya telah mendokumentasikan 8 kampung di Sumba Barat dengan fokus penelitian pada deskripsi morfologi, interior, material, konstruksi. Diantara 8 jenis rumah ini, hanya terdapat 5 kampung yang denah dari rumah adatnya berhasil di dokumentasikan. Lima jenis kampung ini adalah Parona Tossi, Parona Waikahumbu, Parona Ratenggaro, Parona Tarung, dan Paraingu Kabonduk. Seluruh desa tersebut selain Parona Ratenggaro merupakan desa yang berlokasi di kawasan perbukitan, sementara Parona Ratenggaro sendiri berlokasi di kawasan pesisir. Keberagaman jenis kawasan dari kelima desa ini memiliki pengaruh terhadap perbedaan pola denah rumah tinggal dari masing-masing desa (Hariyanto et al, 2012). Sehingga kelima jenis desa ini dinilai cukup mewakili keberagaman kasus pola tatanan ruang yang antara lain disebabkan perbedaan jenis geografis kawasan tersebut (Gambar 9).

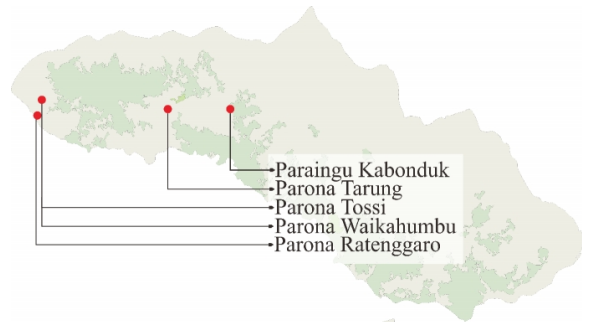

Gambar 9. Posisi masing-masing desa adat dari rumah studi kasus

Dari keseluruhan kasus, terdapat beberapa perbedaan pelabelan ruang meskipun fungsi di dalamnya adalah sama. Agar lebih jelas, beberapa fungsi yang terdapat pada seluruh kasus dengan penamaan yang berbeda tersebut di uraikan dalam Tabel 1.

Tabel 1. Daftar ruang yang memiliki kesamaan fungsi dan perbedaan label

\begin{tabular}{llllll}
\hline Fungsi Dasar & $\begin{array}{l}\text { Parona } \\
\text { Tossi }\end{array}$ & $\begin{array}{l}\text { Parona } \\
\text { Waikahumbu }\end{array}$ & $\begin{array}{l}\text { Parona } \\
\text { Ratenggaro }\end{array}$ & Parona Tarung & $\begin{array}{l}\text { Paraingu } \\
\text { Kabonduk }\end{array}$ \\
\hline Memasak & rabok & Rabok & Dapur & dapur & dapur \\
$\begin{array}{l}\text { Ruang tidur pemilik } \\
\begin{array}{l}\text { Ruang tidur anggota } \\
\text { lain }\end{array}\end{array}$ & ruang besar \\
$\begin{array}{l}\text { R. arwah leluhur } \\
\text { ruang kecil }\end{array}$ & ruang besar & korohanimbaro & punokoro tutungaba & ruang tidur \\
& mata & mata marapu & koro tabalo dape & punokoro & ruang tidur \\
& marapu & & karepadalu & penabakul \\
\hline
\end{tabular}


Ruang-ruang aktivitas yang terdapat pada seluruh kasus tersebut sebagiannya memiliki penamaan yang berbeda meskipun memiliki fungsi yang sama. Sebagai contoh, ruang aktivitas memasak yang dalam Parona Tossi dan Parona Waikahumbu disebut rabok sedangkan dalam Parona Ratenggaro, Parona Tarung, dan Paraingu Kabonduk disebut dapur. Dalam hal ini, pembahasan dari hasil analisis yang dilakukan berpegang pada kesamaan fungsi, alih-alih penamaannya.

\section{Hasil Analisis}

Analisis space syntax yang dilakukan dalam penelitian ini pertama-tama adalah analisis depth. Melalui tahap ini, JPG dari denah yang menjadi kasus digambarkan guna mengidentifikasi tingkat privasi, ruang yang terintegrasi, dan ciri umum lainnya yang dapat diamati. Kemudian tahap integrasi dilakukan untuk mengidentifikasi ruang paling terintegrasi dan ruang paling tersegregasi. Dari kedua tahap analisis di atas, pola yang ada pada keseluruhan hasil analisis diamati untuk dibandingkan antar masing-masing studi kasus.

Pertama tama, analisis depth dilakukan untuk mengungkap secara visual hirarki ruang yang terjadi pada seluruh kasus. JPG yang dibentuk menggunakan eksterior sebagai root. Dengan kata lain, hubungan depth yang dicari adalah dengan asumsi jika seseorang dari luar rumah hendak memasuki bangunan untuk mencapai ruangan tertentu di dalamnya. Kemudian hasil dari JPG ini, berikut dengan denah aslinya, disajikan dalam Tabel 2.

Tabel 1. Hasil analisis depth

Kasus




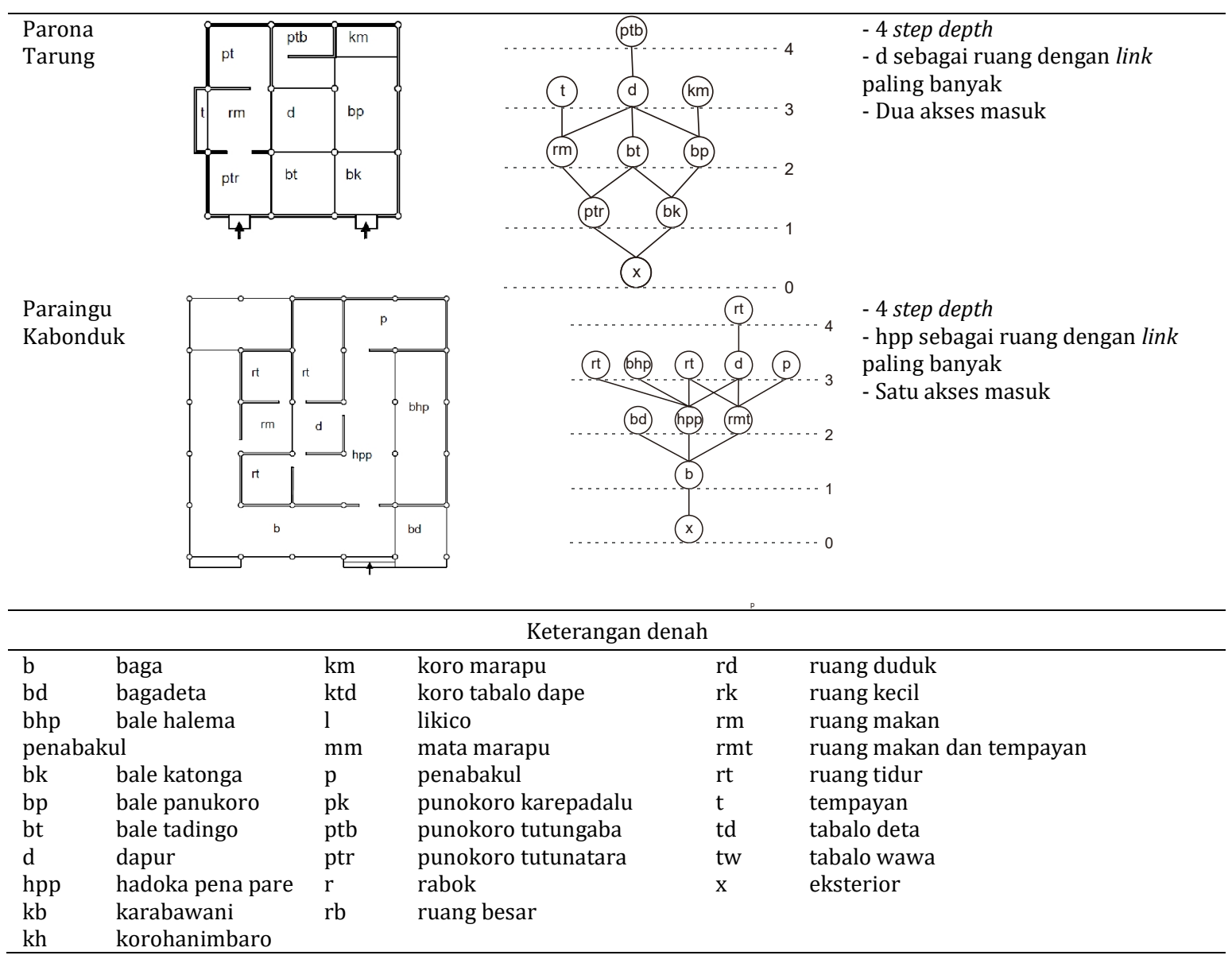

Hasil dari analisis depth mengungkap tiga temuan. Pertama, terlihat bahwa seluruh kasus memiliki empat tingkat hirarki. Hal ini mengindikasikan adanya kualitas spasial dengan sakral-profan yang konsisten. Kedua, tampak bahwa ruang dengan fungsi memasak (rabok/dapur) memiliki keterhubungan tertinggi dibanding ruangan lainnya, kecuali pada Paraingu Kabonduk, yang justru menunjukkan keterhubungan tertinggi pada ruang hadoka pena pare. Ketiga, tampak bahwa masing-masing studi kasus memiliki dua akses masuk kecuali pada rumah jenis Paraingu Kabonduk yang hanya memiliki satu akses masuk.

Selanjutnya, analisis integrasi dilakukan guna menggali hubungan ruang yang telah diungkap melalui tahap depth sebelumnya. Perhitungan nilai integrasi pada kelima kasus dilakukan dengan dua skenario hubungan ruang, yakni dengan melibatkan eksterior dan tanpa melibatkan eksterior (Tabel 3).

Tabel 2. Data nilai integrasi

\begin{tabular}{lccccccccccc}
\hline \multirow{2}{*}{\multicolumn{1}{c}{ Jenis Rumah }} & $\begin{array}{c}\text { Jumlah } \\
\text { cell } \\
\text { interior }\end{array}$ & \multicolumn{4}{c}{ Dengan eksterior } & \multicolumn{4}{c}{ Tanpa eksterior } \\
\cline { 3 - 11 } & & Min & Average & Max & Rentang & Min & Average & Max & Rentang \\
\hline Parona Tossi & 7 & 0,62 & 1,18 & 2,29 & 1,67 & 0,56 & 1,15 & 2,54 & 1,98 \\
Parona Waikahumbu & 8 & 0,55 & 1,14 & 2,21 & 1,66 & 0,53 & 1 & 2,29 & 1,76 \\
Parona Ratenggaro & 11 & 0,55 & 1,07 & 2,23 & 1,68 & 0,53 & 1 & 2,21 & 1,68 \\
Parona Tarung & 10 & 0,73 & 1,26 & 1,89 & 1,16 & 0,68 & 1,23 & 2,2 & 1,52 \\
Paraingu Kabonduk & 10 & 0,69 & 1,15 & 2,21 & 1,52 & 0,64 & 1,12 & 2,2 & 1,56 \\
\hline
\end{tabular}




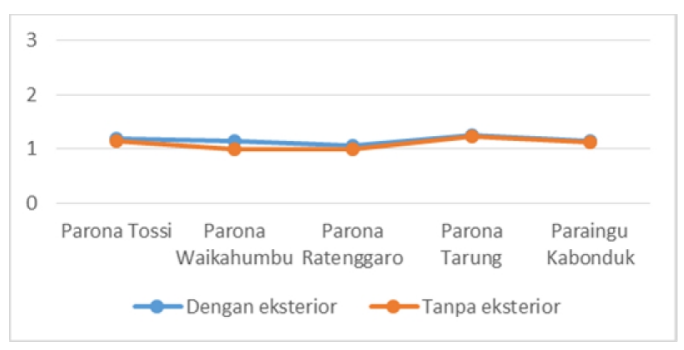

Gambar 10. Grafik konsistensi nilai integrasi rata-rata dari seluruh kasus.

Hasil perhitungan nilai integrasi dari kelima kasus di atas secara umum menunjukkan adanya nilai yang konsisten, baik ketika melibatkan eksterior maupun tidak (Tabel 3). Perbedaan yang cukup signifikan hanya terjadi pada pola nilai integrasi maksimum dan rentang nilai integrasi dari rumah jenis Parona Tarung ketika disejajarkan dengan nilai integrasi maksimum dan rentang nilai integrasi pada jenis rumah lainnya. Meskipun kelima studi kasus memiliki jumlah ruang yang berbeda, namun secara nilai rata-rata integrasi, terdapat pola yang statis, sehingga dapat dikatakan bahwa nilai kepadatan ruang dari seluruh kasus adalah konsisten (Gambar $10)$.

Selanjutnya, untuk melihat tingkatan sakral-profan yang terjadi secara detil, dilakukan perhitungan nilai integrasi untuk masing-masing ruangan pada kelima kasus. Nilai integrasi dari masing-masing ruang dikalkulasi dengan melibatkan eksterior, kemudian diurutkan mulai dari ruang dengan nilai integrasi tertinggi hingga ruang dengan nilai integrasi terendah.

Tabel 4. Tatanan hirarki sakral-profan masing-masing ruang.

\begin{tabular}{|c|c|c|c|c|c|c|c|c|c|c|c|c|c|}
\hline \multirow{2}{*}{ Jenis Rumah } & \multicolumn{13}{|c|}{ Tatanan Integrasi Ruang } \\
\hline & 1 & & 2 & 3 & 4 & 5 & 6 & 7 & 8 & 9 & 10 & 11 & 12 \\
\hline Parona Tossi & $\begin{array}{c}r \\
2.29\end{array}$ & $>$ & $\begin{array}{c}\text { rd } \\
1.72\end{array}$ & $\begin{array}{c}>\mathrm{Rk} \\
1.37\end{array}$ & 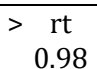 & $=r b$ & $>\quad \begin{array}{c}x \\
0.76\end{array}$ & $>\mathrm{mm}$ & $=\begin{array}{c}1 \\
0.62\end{array}$ & & & & \\
\hline Parona & $\mathrm{r}$ & $>$ & rd & $>\mathrm{Rk}$ & $=r b$ & $=\mathrm{rt}$ & $=x$ & $>\mathrm{rd}$ & $=\mathrm{mm}$ & $>1$ & & & \\
\hline Waikahumbu & 2.21 & & 1.77 & 1.10 & 1.10 & 1.10 & 0.98 & 0.73 & 0.73 & 0.55 & & & \\
\hline Parona & $\mathrm{d}$ & $>$ & $\mathrm{t}$ & $>\mathrm{Tw}$ & $>\operatorname{td}$ & $>$ ktd & $>\mathrm{kh}$ & $=\mathrm{k}$ & $=x$ & $>1$ & $>\mathrm{mm}$ & $>$ ktd & $>1$ \\
\hline Ratenggaro & 2.23 & & 1.56 & 1.30 & 1.20 & 1.04 & 0.92 & 0.92 & 0.92 & 0.87 & 0.68 & 0.62 & 0.55 \\
\hline Parona & $\mathrm{d}$ & $=$ & $\mathrm{rm}$ & $>$ ptr & $>$ bp & $=\mathrm{bk}$ & $>$ bt & $>x$ & $>$ pt & $=\mathrm{t}$ & $=\mathrm{ptb}$ & $>\mathrm{km}$ & \\
\hline Tarung & 1.89 & & 1.89 & 1.65 & 1.47 & 1.47 & 1.32 & 0.94 & 0.82 & 0.82 & 0.82 & 0.73 & \\
\hline Paraingu & hpp & $>$ & $\mathrm{b}$ & $>\mathrm{D}$ & $>\mathrm{rm}$ & $>\mathrm{rt}$ & $=\mathrm{bhp}$ & $=p$ & $>$ bd & $=x$ & $>\mathrm{rt}$ & $=r t$ & \\
\hline Kabonduk & 2.21 & & 1.89 & 1.47 & 1.32 & 0.88 & 0.88 & 0.88 & 0.82 & 0.82 & 0.73 & 0.73 & \\
\hline
\end{tabular}

Melalui Tabel 4, dapat teridentifikasi bahwa ruang dengan nilai integrasi tertinggi dari seluruh kasus kebanyakan adalah ruang dengan aktivitas memasak (dapur dan rabok). Namun, sejalan dengan yang ditunjukkan melalui JPG sebelumnya, konsistensi pola ini tidak terjadi pada jenis rumah Paraingu Kabonduk, yang mana nilai integrasi tertingginya terjadi pada ruang hadoka pena pare. Ruang likico pada kasus Parona Tossi, Parona Waikahumbu, dan Parona Ratenggaro merupakan ruang dengan nilai integrasi terendah. Sementara pada Parona Tarung, ruang dengan nilai integrasi terendah adalah ruang koro marapu, sedangkan pada Paraingu Kabonduk adalah ruang tidur.

Melalui analisis depth dan analisis integrasi, terungkap empat pola yang secara umum konsisten muncul pada masing-masing kasus. Empat pola tersebut di antaranya adalah kesamaan tingkat kedalaman, ruang memasak sebagai area pusat, dua akses masuk, dan konsistensi nilai rata-rata integrasi. Jika keempat pola ini terlihat konsisten pada beberapa jenis rumah, maka dapat dikatakan bahwa studi kasus yang ada mengandung genotype yang kuat, sedangkan jika terlihat perbedaan pola yang menonjol 
pada salah satu rumah, maka dapat dikatakan bahwa rumah tersebut memiliki genotype yang tidak begitu kuat.

Tabel 3. Identifikasi genotype

\begin{tabular}{llccccc}
\hline $\begin{array}{l}\text { Properti } \\
\text { Analisis }\end{array}$ & Unsur genotype & $\begin{array}{c}\text { Parona } \\
\text { Tossi }\end{array}$ & $\begin{array}{c}\text { Parona } \\
\text { Waikahumbu }\end{array}$ & $\begin{array}{c}\text { Parona } \\
\text { Ratenggaro }\end{array}$ & $\begin{array}{c}\text { Parona } \\
\text { Tarung }\end{array}$ & $\begin{array}{c}\text { Paraingu } \\
\text { Kabonduk }\end{array}$ \\
\hline $\begin{array}{l}\text { Depth } \\
\text { Depth } \\
\text { +Integrasi }\end{array}$ & $\begin{array}{l}\text { 4 tingkat kedalaman } \\
\text { Repth }\end{array}$ & $\checkmark$ & $\checkmark$ & $\checkmark$ & $\checkmark$ & $\checkmark$ \\
$\begin{array}{l}\text { sebagai area pusat } \\
\text { Integrasi }\end{array}$ & $\begin{array}{l}\text { Lua akses masuk } \\
\text { Konsistensi nilai } \\
\text { rata-rata integrasi }\end{array}$ & $\checkmark$ & $\checkmark$ & $\checkmark$ & $\checkmark$ & $\times$ \\
Genotype & $(1-1,26)$ & $\checkmark$ & $\checkmark$ & $\checkmark$ & $\checkmark$ & $\checkmark$ \\
\hline
\end{tabular}

Pada Tabel 5, terlihat bahwa jenis rumah Parona Tossi, Parona Waikahumbu, Parona Ratenggaro, serta Parona Tarung mengandung semua pola yang didapat dari hasil analisis space syntax. Oleh sebab itu, maka keempat jenis rumah ini memiliki genotype yang kuat. Sementara pada studi kasus Paraingu Kabonduk, terlihat bahwa terdapat pola yang benar-benar berbeda dengan keempat studi kasus lainnya. Oleh sebab itu, jenis rumah ini dapat digolongkan sebagai rumah Sumba Barat dengan genotype yang dianggap berbeda.

\section{Diskusi Dan Interpretasi}

Dari hasil identifikasi genotype, didapat empat rumah Sumba dengan genotype yang kuat dan satu rumah dengan genotype yang berbeda. Sesuai dengan tujuan dari analisis space syntax, maka dapat ditarik kesimpulan bahwa perbedaan genotype ini mengindikasikan adanya perbedaan fenomena sosial antara masyarakat di desa Paraingu Kabonduk.

Rumah Paraingu Kabonduk, yang memiliki genotype berbeda ini, menurut Winandari (2006) dalam penelitiannya merupakan rumah jenis rumah Sumba Barat yang telah mengalami pengaruh modernisasi. Meskipun secara eksterior rumah ini tidak berbeda dengan jenis rumah lainnya, namun hal ini diindikasikan melalui sistem konstruksinya yang tidak lagi menggunakan kayu utuh sebagaimana keempat rumah lainnya, melainkan menggunakan kayu balok olahan. Dampak modernisasi yang telah terbukti mempengaruhi pandangan masyarakat mengenai material konstruksi ini dapat menjadi indikasi adanya pergeseran nilai sosial dari masyarakatnya, yang mana hal ini juga besar kemungkinan termanifestasi pula dalam konfigurasi ruang interiornya. Jika dilihat dari denahnya, rumah ini memiliki ukuran yang lebih luas dibanding jenis rumah yang lainnya. Meskipun fungsi-fungsi dasar Rumah Sumba seperti ruang memasak dan ruang pemujaan Marapu ini masih terdapat dalam rumah Paraingu Kabonduk, tetapi hasil analisis mengindikasikan adanya perbedaan pemaknaan ruang dalam kaitannya dengan core dan territory. Adanya beberapa unsur yang berbeda dari rumah ini mengindikasikan bahwa rumah Paraingu Kabonduk ini telah mengalami transformasi yang membawanya keluar batas dari pola spasial yang terdapat pada keempat studi kasus lainnya.

Pada keempat desa lainnya yang tergolong memiliki genotype yang kuat, tampak bahwa tidak terjadi modernisasi yang signifikan yang berpengaruh terhadap tatanan ruangnya. Sistem kepercayaan Marapu dan sistem sosial tradisional Sumba yang mempengaruhi konfigurasi ruang pada rumah di keempat desa ini masih tampak jelas berperan kuat dan telah terbukti. Dengan adanya konsistensi pola spasial dari rumah di keempat desa ini, maka dapat dikatakan bahwa rumah adat di keempat desa ini masih 
memegang nilai kepercayaan maupun sosial yang kuat, yang mana hal ini termanifestasi pula dalam konfigurasi ruangnya yang terbukti konsisten.

Menurut Rapoport (1969), pengaruh dari arsitektur rumah dalam suatu masyarakat bukanlah hanya dari dorongan fisik saja (material, site, iklim), melainkan lebih sebagai konsekuensi dari kondisi sosio-kultur masyarakat tersebut. Tambahnya pula, pengaruh sosio-kultur ini merupakan pengaruh yang lebih utama dibanding dorongan fisik tersebut. Jika teori tersebut mengatakan bahwa wujud arsitektur merupakan manifestasi dari kondisi sosio-kultur suatu masyarakat, maka teori space syntax mengatakan sebaliknya bahwa fenomena sosio-kultur yang ada pada masyarakat dapat digali melalui wujud arsitekturnya (Dawson, 2002). Hubungan timbal balik dari kedua teori tersebut menunjukkan bahwa jika di antara satu golongan masyarakat yang sama terdapat satu produk arsitektur dengan tatanan ruang yang berbeda dari umumnya, maka pada arsitektur yang berbeda tersebut, terdapat kemungkinan adanya pergeseran nilai dan budaya.

\section{Kesimpulan}

Hasil dari penelitian ini mengungkap temuan bahwa rumah adat Sumba Barat di Parona Tossi, Parona Waikahumbu, Parona Ratenggaro, dan Parona Tarung tergolong sebagai rumah Sumba Barat dengan genotype yang kuat. Sementara rumah Paraingu Kabonduk tergolong sebagai rumah dengan genotype yang berbeda. Pola konfigurasi ruang yang menjadi benang merah dalam menentukan genotype tersebut di antaranya adalah empat tingkat kedalaman, ruang memasak sebagai area pusat, dua akses masuk, serta konsistensi nilai rata-rata integrasi. Sesuai dengan tujuan space syntax, maka hasil dari identifikasi genotype ini berperan sebagai dasar dalam mengungkap fenomena sosial yang terjadi dalam masyarakat Sumba Barat, dalam hal ini, adanya pengaruh modernisasi yang kuat pada desa Paraingu Kabonduk, yang telah terbukti melalui arsitekturnya.

Penelitian ini memiliki kebaruan pada aspek metodologi, yang mana pada penelitian sebelumnya aspek spasial ini diamati dengan metode yang berbeda. Dengan menggunakan metode space syntax dalam menggali core dan territory suatu bangunan, maka faktor-faktor tersebut dapat terbukti secara kuantitatif. Namun, sebagaimana penelitian yang menggunakan metode space syntax lainnya yang mengandalkan artefak berupa denah, tidak menutup kemungkinan di dalam penelitian ini terdapat aspek konfigurasi ruang lainnya yang telah direduksi dalam proses analisis, seperti faktor perbedaan ketinggian ruangan, sifat dari pembatas ruangan, serta aspek dimensi dan satuan jarak dari obyek yang dikaji.

Adapun kemungkinan yang dapat digali pada penelitian selanjutnya adalah studi terkait transformasi arsitektur rumah tradisional Sumba sebagai akibat dari modernisasi, ataupun program pariwisata yang kini semakin berkembang. Selain itu, dapat pula dilakukan studi proyektif berupa eksplorasi spasial rumah tradisional Sumba sebagai salah satu upaya meng-konteks-kan arsitektur Nusantara dalam perancangan arsitektur kontemporer.

\section{Daftar Pustaka}

Adeokun, C. O. (2013). The Orowa House: A Typology of Traditional Yoruba Architecture in Ile-Ife. In West Africa Built Environment Research.

Dawson, P. C. (2002). Space syntax analysis of Central Inuit snow houses. Journal of Anthropological Archaeology, 21(4), 464-480. https://doi.org/10.1016/S02784165(02)00009-0 
Hariyanto, A. D., Asri, A., Nurdiah, E. A., \& Tulistyantoro, L. (2012). Hubungan Ruang, Bentuk, dan Makna pada Arsitektur Tradisional Sumba Barat. Surabaya: Lembaga Penelitian dan Pengabdian Kepada Masyarakat Universitas Kristen Petra.

Hillier, B. (1984). The social logic of space. The Social Logic of Space, 247-249. https://doi.org/10.1016/0169-2046(86)90038-1

Hillier, B., Hanson, J., \& Graham, H. (1987). Ideas are in things: an application of the space syntax method to discovering house genotypes, 14, 363-385.

I. Numan, O. D. (2005). The Transformation Opportunities of Cypriot Vernacular Houses under the Scope of Tourism. World Congress on Housing: Transforming Housing Environments through Design. Pretoria: IAHS.

Machdijar, L. K., Topan, M. A., Winandari, M. I., \& Sofian, I. (2007). Megalitik Arsitektur Tradisional Sumba. Yogyakarta: Graha Ilmu.

Mross, J. (1995). Environmentally Responsive Design in the Settlement of the Cockatoo. 1st International Symposium on Asia Pacific Architecture: The East-West Encounter. Honolulu: University of Hawaii at Manoa.

Nazidizaji, S., \& Safari, H. (2014). The social logic of Persian houses, in search of the introverted houses genotype. World Applied Sciences Journal, 31(5), 785-793. https://doi.org/10.5829/idosi.wasj.2014.31.05.1604

Nepal, S. (2010). Tourism and Remote Mountain Settlements: Spatial and Temporal Development of Tourist Infrastructure in the Mt Everest Region, Nepal. Tourism Geographies: An International Journal of Tourism Space, Place and Environment, 7(2), 205-227.

Rapoport, A. (1977). Human Aspects of Urban Form. Oxford: Pergamon Press.

Rapoport, A. (1969). House Form and Culture. Cultural Geography Series. New Jersey: Prentice-Hall, Inc.

Suprijanto, I. d. (2009). Penelitian dan Pengkajian Kehandalan Bangunan Tradisional. Denpasar: Balai Pengembangan Teknologi Perumahan Tradisional.

Thungsakul, N. (2001). A Syntactic Analysis of Spatial Configuration Towards The Understanding of Continuity And Change In Vernacular Living Space: A Case Study In The Upper Notheast of Thailand. Florida: University of Florida.

Tim Peneliti Widya Mandira. (1992). Arsitektur Vernakular. Kupang: Fakultas Teknik Arsitektur Universitas Widya Mandira.

Topan, M. A. (2005). Morfologi Arsitektur Sumba. Jurnal Penelitian dan Karya Ilmiah Lemlit USAKTI 17, 69-83.

Winandari, M. I. (2006). Arsitektur Tradisional Sumba. Jakarta: Universitas Trisakti. 